\title{
„Dajcie mi rewolwer, a poruszę wszystkie budynki” Architektura z punktu widzenia Teorii Aktora-Sieci (ANT) ${ }^{1}$
}

\section{Bruno Latour}

Sciences Po médialab, Francja
Albena Yaneva

University of Manchester, UK

Przekład i opracowanie: Ewa Bińczyk, Jakub Gużyński

Przekład otrzymano 8 lutego 2018, zaakceptowano 22 lutego 2018, opublikowano zimą 2018/2019.

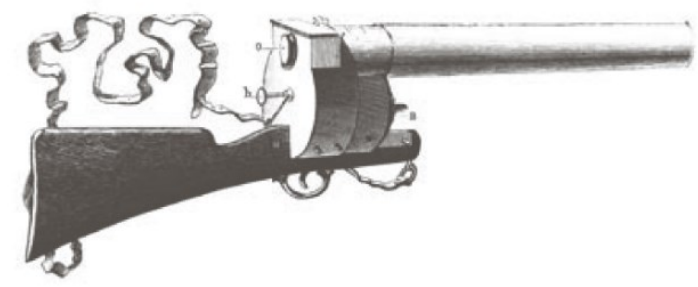

Ilustracja 1

\begin{abstract}
Abstrakt
Nasz problem z budynkami to dokładne przeciwieństwo problemu, z którym zmagał się Etienne Jules Marey, przeprowadzając swoje słynne badanie fizjologii ruchu. Przy pomocy wynalezionego przez siebie „fotorewolweru” (ilustracja 1) chciał on uchwycić lot mewy w taki sposób, żeby móc zobaczyć każdą stopklatkę płynnego ruchu, którego mechanizm wymykał się obserwatorom aż do momentu pojawienia się tego właśnie wynalazku (ilustracja 2 i 3). My potrzebujemy czegoś przeciwnego, problem z budynkami polega bowiem na tym, że wydają się one dramatycznie statyczne. Uchwycenie ich jako ruchu, lotu czy serii przemian wydaje się prawie niemożliwe. Wszyscy - zwłaszcza architekci - wiedzą,

\footnotetext{
${ }^{1}$ Źródło: Give Me a Gun and I Will Make All Buildings Move: an ANT's View of Architecture, w: Reto Geiser (red.), Explorations in Architecture: Teaching, Design, Research, 2008, Basel: Birkhäuser, s. 80-89. Redaktorzy numeru dziękują Panu Wojciechowi Bagińskiemu z Muzeum Pałacu Króla Jana III w Wilanowie za zwrócenie uwagi na ten tekst. Zaznaczmy, że tytuł tekstu Latoura i Yanevej nawiązuje nie tylko do powiedzenia Archimedesa, ale też do tytułu wcześniejszego artykułu Latoura: Dajcie mi laboratorium a poruszę świat, przeł. Krzysztof Abriszewski, Łukasz Afeltowicz, w: Ewa Bińczyk, Aleksandra Derra (red.). Studia nad nauka oraz technologia.
} Wybór tekstów, 2014, Toruń: Wydawnictwo Naukowe UMK, s. 139-178 [przyp. thum].
\end{abstract}


że budynek nie jest statycznym obiektem, ale raczej dynamicznym projektem. Nawet kiedy zostanie już wybudowany, każdy budynek zaczyna się starzeć, jest przekształcany przez użytkowników, a także modyfikowany przez wszystko, co wydarza się na zewnątrz i wewnątrz. Przeminie on lub zostanie odnowiony przy użyciu nowych materiałów, często zmieniony nie do poznania. Wiemy to wszystko, lecz problemem pozostaje to, że nie dysponujemy odpowiednikiem fotorewolweru Marey'a: kiedy myślimy o budynku, jest on zawsze nieruchomą, obojętną strukturą, przedstawianą w barwach procesowych ${ }^{2}$ na błyszczących stronach czasopism, przerzucanych przez klientów siedzących w poczekalniach biur projektowych. Skoro niemożność sfotografowania lotu mewy jako serii następujących po sobie stopklatek tak bardzo frustrowała Marey’a, jakże irytująca musi być dla nas niemożność zobrazowania płynności i ciągłego ruchu konstytuującego każdy budynek. W oparciu o dostępne mu dane wzrokowe Marey mógł ustalić fizjologię lotu dopiero po wynalezieniu sztucznego urządzenia (fotorewolweru). My również potrzebujemy narzędzia (w tym przypadku teorii), abyśmy mogli przemienić statyczny obraz budynku w serię następujących po sobie stopklatek, które ostatecznie pokażą, że każdy budynek to tak naprawdę dynamiczny projekt (ilustracja 4).

Słowa kluczowe: ANT; architektura; budynek; ruch; projekt.

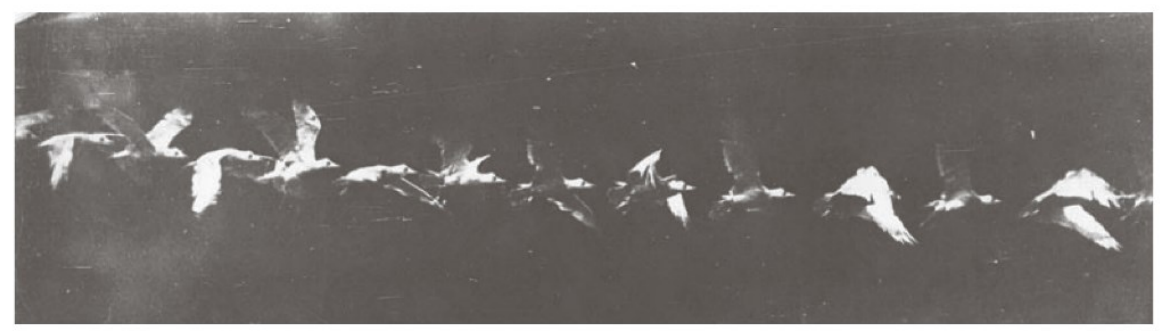

\section{Ilustracja 2}

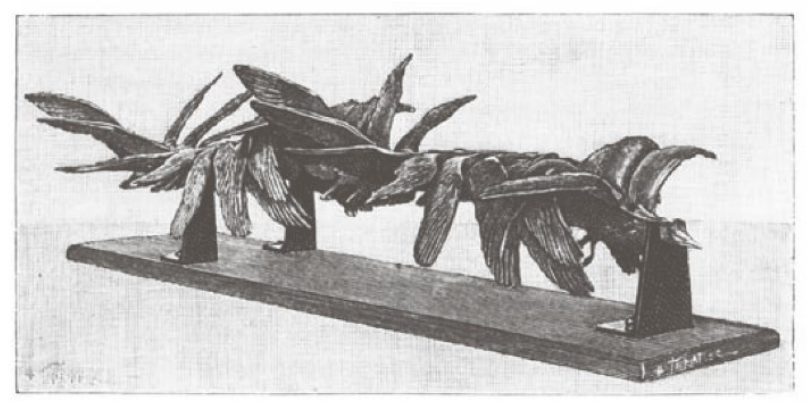

\section{Ilustracja 3}

\footnotetext{
${ }^{2}$ Chodzi o tzw. kolory triadowe lub barwy procesowe CMYK (cyjan, magneta, żółty i czarny), stosowane w druku wielobarwnym w poligrafii [przyp. thum.].
} 


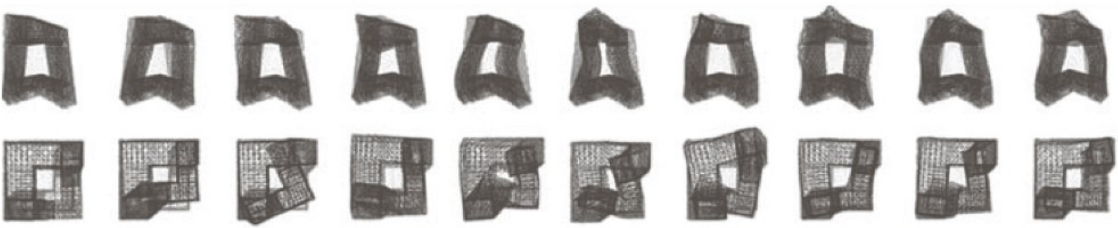

Ilustracja 4

Prawdopodobnie piękno i ogromna atrakcyjność rysunku perspektywicznego przyczyniły się do rozpowszechnienia przekonania, że budynki to struktury statyczne. Oczywiście życie nie toczy się w przestrzeni euklidesowej; byłoby to niemożliwe, a dodanie „,czwartego wymiaru" (jakim jest czas) nie sprawi, że uzyskany w ten sposób układ współrzędnych stanie się lepszym polem manewru dla naszych skomplikowanych aktywności. Kiedy jednak rysuje się budynek w wynalezionym $w$ renesansie rzucie perspektywicznym (prawie niezmienionym przez wykorzystanie technik komputerowych w projektowaniu - może z wyjątkiem tego, że dzięki nim rzut perspektywiczny stał się bardziej mobilny), zaczyna się wierzyć, że przestrzeń euklidesowa umożliwia realistyczny opis. Statyczny obraz budynków to ryzyko zawodowe, na które narażeni są wszyscy, którzy rysują je zbyt poprawnie.

Nie powinno tak być, ponieważ obrazowanie przy użyciu trójwymiarowego projektowania komputerowego (CAD) jest całkowicie nierealistyczne. Gdzie na takim obrazie umieścić zdenerwowanych klientów z ich niekiedy sprzecznymi żądaniami? Gdzie uwidocznić zapisy prawa i ograniczenia ze strony planów miejscowych? Gdzie ulokować finansowanie i różne warianty budżetu? Jak pokazać logistykę kolejnych transakcji? Gdzie usytuować ocenę subtelnych różnic między mniej lub bardziej doświadczonymi specjalistami? Jak zarchiwizować mnóstwo kolejnych modeli, z konieczności modyfikowanych w ten sposób, żeby uwzględnić nieprzerwany strumień postulatów płynących ze strony tak wielu skonfliktowanych ze sobą interesariuszy - użytkowników, społeczności sąsiedzkich, konserwatorów, klientów, przedstawicieli rządu i władz miejskich? Jak włączyć w to zmieniającą się specyfikę programu? Wystarczy minuta refleksji, aby przyznać, że przestrzeń euklidesowa to tylko przestrzeń, w której budynki są rysowane na papierze, a nie środowisko, w którym są one budowane, ani tym bardziej świat, w jakim się ich „doświadcza”. Wracamy w ten sposób do odwróconego problemu Marey'a: każdy zgodzi się, że martwa mewa nie mówi zbyt wiele na temat sposobu, w jaki ptak ten lata. Przed wynalezieniem fotografii poklatkowej można było jedynie badać martwe mewy. Nie ma wątpliwości, że rysunek (lub fotografia) budynku jako obiektu nie mówi nam niczego o „locie” budynku rozumianego jako projekt. Ciągle jednak odwołujemy się do przestrzeni euklidesowej, która stanowi jedyne narzędzie pozwalające „uchwycić”, czym jest budynek - tylko po to, żeby wciąż uskarżać się na to, jak wiele wymiarów ona pomija. Uznanie budynku za statyczny obiekt jest jak niekończące się obserwowanie mewy wysoko na niebie, bez możliwości uchwycenia istoty jej ruchu. 
Dobrze wiemy, że żyjemy w świecie zupełnie odmiennym od przestrzeni euklidesowej: fenomenolodzy (i psychologowie ze szkoły Gibsona ${ }^{3}$ ) niezmordowanie pokazują nam, że między sposobem, w jaki ucieleśniony umysł doświadcza swojego otoczenia, a „obiektywnym” kształtem, przypisywanym „materialnym” obiektom istnieje przepaść. Badacze ci próbowali do „galileuszowych” ciał przetaczających się przez przestrzeń euklidesową dodać „ludzkie” ciała przemierzające ,przeżywane” przez człowieka środowisko (Vesely, 2004; Holl, Pallasmaa, Pérez-Gómez, 2006). Mimo że podejście to wydaje się rozsądne, na gruncie architektury na niewiele nam się ono przydaje. Prowadzi do odtworzenia powszechnie stosowanego podziału na wymiar subiektywny i obiektywny, który zawsze paraliżował teorię architektury, nie wspominając o wynikającym z niego automatycznym przeciwstawianiu sobie zawodów architekta i inżyniera (ani o katastrofalnych skutkach tego dualizmu dla samej filozofii). Podejście to jest tak dziwne, gdyż bierze się tu za pewnik, że inżynierskie rysunki na kartce papieru i zastosowanie geometrii rzutowej adekwatnie opisują tak zwany świat „materialny”. Jest to ukryte założenie całej fenomenologii: mówi ona o konieczności dodania ludzkiego, subiektywnego i intencjonalnego wymiaru do świata „materialnego”, który prawidłowo opisują geometryczne kształty i matematyczne obliczenia. Paradoksalną konsekwencją specyficznego podziału pracy, zaprojektowanego przez tych, którzy chcą dodawać wymiar „przeżyć” charakteryzujący perspektywę ludzką do „obiektywnych” warunków materialnego istnienia jest to, że aby uniknąć redukowania ludzi do przedmiotów, muszą oni najpierw zredukować przedmioty do rysunków. Jednak nie tylko architekci i architektki, ich klienci, przechodnie de Certeau czy flaneurzy Benjamina nie żyją w przestrzeni euklidesowej - dotyczy to również budynków! O ile niesprawiedliwe jest „,materializowanie” ludzkiego doświadczenia, o tyle tym bardziej niesprawiedliwe jest redukowanie materii do tego, co może być narysowane. Materia nie znajduje się „w” przestrzeni euklidesowej, bowiem przestrzeń ta stanowi jedynie nasz własny sposób odbierania przedmiotów (ich poznawania i manipulowania nimi), umożliwiający nam poruszanie nimi bez ich przekształcania (z zachowaniem ich wybranych właściwości). Z pewnością nie jest to tryb, w jakim byty materialne (drewno, stal, przestrzeń, czas, farba, marmur itp.) przekształcają się w celu utrzymania swojego istnienia. Res extensa Kartezjusza nie stanowi metafizycznej właściwości świata. Jest ona jedynie efektem bardzo specyficznej, posiadającej swoją historię i techniczne ograniczenia metody cieniowania i rysowania kształtów na papierze w sposób, który uległ silnej konwencjonalizacji. Idąc krok dalej w tym (bezsprzecznie filozoficznym) rozumowaniu, można powiedzieć, że przestrzeń euklidesowa jest raczej subiektywnym, antropocentrycznym lub co najmniej wiedzocentrycznym sposobem pojmowania bytów, który nie oddaje tego, jak ludzie $i$ rzeczy radzą sobie w świecie. Jeśli można wychwalać fenomenologię za to, że opiera się ona pokusie redukowania ludzi do rzeczy, powinna być zarazem wyraźnie zganiona za uleganie jeszcze silniejszej i bardziej destrukcyjnej pokusie redukowania materialności do tego, co obiektywne.

\footnotetext{
${ }^{3}$ Chodzi o Jamesa J. Gibsona (1904-1979), amerykańskiego psychologa, filozofa umysłu i badacza percepcji, autora koncepcji afordancji. Zob. Gibson, 1979 [przyp. thum.].
} 
Co jeszcze bardziej niezwykłe, sławna przestrzeń euklidesowa, przez którą obiekty galileuszowe toczyć się mają niczym kule, wcale adekwatnie nie opisuje czynności rysowania budynku. Najlepiej świadczy o tym konieczność sporządzania przez architekta lub architektkę, nawet w najwcześniejszej fazie projektowania, wielu modeli (czasami fizycznych), jak również stosowania wielu różnych rodzajów rysunku - wszystko po to, by wyrazić zamysł autorki lub autora i sprawdzić, jak wielu różnych interesariuszy można w toku projektowania wziąć jednocześnie pod uwagę. Energia umysłowa architekta czy fantazje zrodzone w jego wyobraźni nie przekładają się bezpośrednio na rysunek czy model. Nie jest to proces przenoszenia idei z umysłu projektanta do świata fizycznego (Porter, 1979) ani też przekładania potęgi „,subiektywnej” wyobraźni na „materialne” ekspresje różnego rodzaju (Busch, 1991). Jest raczej tak, że setki modeli i rysunków wykonanych w trakcie projektowania to artystyczny materiał bazowy, który rozbudza wyobraźnię haptyczną (Bredekamp, 2004, s. 11-29), zaskakując swoich twórców, zamiast im posłusznie służyć. Modele i rysunki pomagają architektom uporać się z nowymi ideami, zgromadzić wiedzę o budynku, który ma powstać, a także sformułować kolejne alternatywy i „opcje” - nowe, nieprzewidziane wcześniej scenariusze realizacji. Śledzenie ewolucji rysunków powstających w pracowni architekta jest jak obserwowanie wysiłków żonglera, który ciągle dodaje kolejne piłki do swego wymagającego zręczności, akrobatycznego pokazu. Każda nowa technika rysunkowa czy modelarska służy przezwyciężeniu nowej trudności. Techniki tego rodzaju składają się na zbiór narzędzi niezbędnych do podjęcia próby zbudowania czegokolwiek. Byłoby po prostu niewłaściwe ograniczać do trzech wymiarów działanie, które z definicji opiera się na systematycznym gromadzeniu coraz większej ilości kolejnych wymiarów po to, aby ostatecznie „uzyskać” realny budynek, zdolny do stawienia oporu przeciwnościom. Za każdym razem jakaś nowa przeszkoda musi być wzięta pod uwagę - ograniczenie przestrzenne, nowa konstrukcja budynku, zmiana w schemacie finansowania, protest obywatelski, odporność takiego czy innego materiału, moda, obawy klienta, nieznana wcześniej idea wpływająca na styl myślenia w pracowni. Konieczne jest wtedy wymyślenie nowego sposobu rysowania, aby uwzględnić przeszkodę, dopasowując ją do wszystkich pozostałych elementów.

Podczas swojego „lotu” budynek zatem nigdynie pozostaje w spoczynku i nigdy nie ma kształtu właściwego dla przestrzeni euklidesowej, która rzekomo oddaje jego „prawdziwą, materialną istotę” i którą dopiero można uzupełniać o wymiar „symboliczny”, „ludzki”, „subiektywny” czy „ikoniczny”. Bardzo często modele, rysunki i sam budynek występują obok siebie - symultanicznie poprawiane i ulepszane. W czasie budowy, na oczach zadziwionych robotników i inżynierów, architekci bezustannie krążą między powstającym budynkiem a swoimi licznymi rysunkami oraz modelami, dokonując porównań, poprawek i uaktualnień. Rysunki architektoniczne, przekształcone w projekty inżynierskie, a następnie w wielu wersjach przekazywane pracownikom na budowie (przyklejane na ścianach, składane w aktówkach, poplamione kawą czy farbą) przechodzą oszałamiają liczbę zmian. Żadna z nich nie ogranicza się do „trzech” wymiarów... Kiedy robotnik lub robotnica potwierdza przez podpis na rysunku, że rozumie swoje zadanie, mamy do czynienia z długością, szerokością czy wysokością? Kiedy uzgadnia się normy prawne z projektem 
(zachowując określony margines tolerancji) - do którego z wymiarów w przestrzeni euklidesowej się to odnosi? Strumień przemian nie ustaje, ponieważ wraz z ukończeniem budowy pojawia się nowy problem dotyczący opisu: budynek okazuje się trudny do przeniknięcia dla tych, którzy mają go obsługiwać i konserwować. W tym momencie znowu potrzebujemy zupełnie nowych diagramów, schematów postępowania, tablic i etykiet, żeby zarchiwizować i zapamiętać, gdzie co się znajduje i jak się do tego dostać, gdy dojdzie do wypadku lub gdy konieczna okaże się naprawa. Budynek, podczas serii transformacji na gruncie wielu różnych rodzajów zapisu towarzyszących jego „lotowi”, ani przez chwilę nie znajduje się zatem w przestrzeni euklidesowej. Cały czas myślimy jednak o budynku tak, jakby w swojej istocie nie różnił się od białego sześcianu, który jako res extensa został poddany translacji, nie ulegając jednak żadnym zmianom.

Co zyskujemy, porzucając statyczną wizję budynków i ujmując je w zamian (dzięki zastosowaniu teoretycznego ekwiwalentu fotorewolweru Marey'a) jako strumienie przemian? Pierwszą z korzyści jest oczywiście porzucenie podziału na wymiar „subiektywny” i ,obiektywny”.

Inną korzyścią byłoby oddanie wreszcie sprawiedliwości temu, że rzeczy posiadają wiele wymiarów materialnych (bez odgórnego ograniczania ich do epistemologicznego kaftana bezpieczeństwa trójwymiarowych manipulacji w przestrzeni). Materia jest nazbyt wielowymiarowa, zbyt aktywna, złożona, zaskakująca i kontrintuicyjna, by sprowadzać ją do zamglonego obrazu z CAD-owskich zrzutów ekranu. Projektowanie architektoniczne obejmuje złożoną mieszankę wielu zaskakujących rodzajów sprawczości, rzadko branych pod uwagę przez teorię architektury. Jak powiedział William James, jako byty materialne żyjemy w „pluriwersum”, a nie uniwersum. Tego rodzaju ujęcie projektowania ujawnia, jak bardzo architekci przywiązani są do czynników pozaludzkich, takich jak modele fizyczne i narzędzia konieczne do ich stworzenia ${ }^{4}$, programy umożliwiające renderowanie ${ }^{5}$ i komputery ${ }^{6}$. Architekci w zasadzie nie umieliby wyobrazić sobie budynku, gdyby nie wsparcie i swoiste wzmocnienie potencjału motorycznego wielu myślących, rysujących i tworzących modele rąk. To właśnie czyni architektów tak istotnymi z punktu widzenia tego, co materialne. Nawet najskromniejsze badanie z zakresu antropologii architektury, najdrobniejszy eksperyment odnoszący się do materiałów i kształtów pokazuje, że aby przeprowadzić najprostszą procedurę wizualizacji nowego budynku, każdy architekt potrzebuje najróżniejszych przyrządów - pomocy dla wyobraźni i narzędzi myślenia połączonych z ciałem. Następną korzyścią byłoby to, że przeróżne oczekiwania ludzi mogłyby wreszcie zostać umieszczone w tej samej przestrzeni optycznej, co sam budynek, którym

\footnotetext{
${ }^{4}$ W zastosowaniu Rema Koolhasa: zob. A. Yaneva, 2005, s. 867-894.

${ }^{5}$ Renderowanie (często wykorzystywane w grafice trójwymiarowej) to przedstawienie informacji zawartych w dokumencie elektronicznym w formie najbardziej właściwej dla danego środowiska, np. graficznej lub dźwiękowej. Renderowanie może na przykład dotyczyć przetworzenia obrazu dwuwymiarowego na trójwymiarowy [przyp. thum.].

${ }^{6}$ W zastosowaniu Kengo Kuma: zob. Houdart, 2006, s. 107-122.
} 
ludzie ci są tak bardzo zainteresowani. Twierdzić, że budynek zawsze jest „rzeczą” (thing), czyli - sięgając do etymologii - zgromadzeniem ${ }^{7}$ sprzecznych postulatów, o które toczy się walka, i równocześnie być całkowicie niezdolnym do narysowania tych sprzecznych roszczeń w tej samej przestrzeni, w której rysuje się to, czego spór dotyczy... Zakrawa to na paradoks. Każdy wie, że budynek jest terytorium spornym i nie można go redukować ani do tego, co istnieje, ani do znaczenia tego czegoś (jak głosiła dotąd teoria architektury (Bonta, 1979; Jencks, Baird, 1969; Venturi, Brown, 2004)). Tylko przez wyliczenie ruchów i staranne rozważenie „boleści” budynku, można potwierdzić jego istnienie. Oznaczałoby to sporządzenie obszernej listy kontrowersji i działań rozciągniętych w czasie, tzn. opisanie tego, co budynek robi, jak opiera się próbom dokonania przekształceń, pozwalając na pewne zachowania i utrudniając inne, drażniąc obserwatorów, sprawiając trudności władzom miejskim i mobilizując kolejne wspólnoty aktorów. My jednak albo widzimy niekontrowersyjny, statyczny obiekt stojący „tam na zewnątrz”, gotowy na reinterpretacje, albo słyszymy o sprzecznych ludzkich zamiarach. Nigdy nie jesteśmy w stanie ująć obu tych wymiarów równocześnie! Prawie cztery stulecia po wynalezieniu rysunku perspektywicznego i ponad dwieście lat po wynalezieniu geometrii wykreślnej (co możemy przypisać Gaspardowi Monge, rodakowi Marey’a z maleńkiego burgundzkiego miasteczka Beaune!) wciąż nie mamy przekonującego sposobu pozwalającego nam rozrysować pełną kontrowersji przestrzeń, jaką prawie zawsze jest budynek. Trudno uwierzyć, że potężne narzędzia umożliwiające wizualizację, którymi obecnie dysponujemy, wciąż nie pozwalają nam osiągnąć więcej niż to, czego umieli dokonać Leonardo, Dürer czy Piero (Latour, 2008, s. 122-136). Powinniśmy wreszcie nauczyć się przedstawiać budynek jako nawigowanie przez pełną kontrowersji przestrzeń danych: jako ożywioną serię projektów zakończonych sukcesem lub niepowodzeniem, zmieniającą się i splataną trajektorię zmiennych definicji i ekspertyz, stawiających opór materiałów i technologii budowlanych, wycen proponowanych przez poszczególne wspólnoty i obaw użytkowników, którzy często zmieniają zdanie. Powinniśmy nareszcie nauczyć się przedstawiać budynek jako modulator regulujący różne stopnie zaangażowania, przekierowujący uwagę użytkowników, przemieszczający i łączący ludzi, koncentrujący przepływy aktorów i umożliwiający ich dystrybucję w celu ustanowienia produktywnej siły osadzonej w czasoprzestrzeni. Zamiast biernie zajmować odgórnie wyodrębnioną przestrzeń, budynek-wruchu nie ma już nic wspólnego z przestrzeniami, które okrzyknięto zamkniętymi i w ten sposób skonceptualizowano. W zamian budynek-w-ruchu z łatwością porusza się w obwodach otwartych. Dlatego, podobnie jak mewę-w-locie w złożonej i wieloświatowej, dynamicznej przestrzeni, budynek konstytuują otwarcia i zamknięcia umożliwiające, utrudniające czy modyfikujące prędkość swobodnie poruszających się aktorów, danych i zasobów, powiązań i opinii, krążących na orbitach czy w sieci, nie pozwalających na to, by zamknąć je wszystkie $w$ statycznej przestrzeni (zob. projekt MACOSPOL ${ }^{8}$ ).

\footnotetext{
${ }^{7}$ Angielskie słowo thing odnosi się do publicznego zebrania [przyp. tłum.].

${ }^{8}$ MACOSPOL (Mapping Controversies on Science for Politics) to zainicjowany przez Latoura projekt badawczy
} 
Jedną z pozostałych korzyści ujmowania budynku jak mewy-w-locie byłaby możliwość pozbycia się kontekstu. „Kontekst śmierdzi”, jak głosi słynne stwierdzenie Koolhaasa. Śmierdzi on jednak tylko dlatego, że pozostając zbyt długo w jednym miejscu zaczął się rozkładać. Nie byłoby tego problemu, gdybyśmy dostrzegli, że kontekst również jest w ruchu i zmienia się tak samo jak budynki. Czym jest kontekst w locie? Składa się on z wielu wymiarów, które kolidują ze sobą w każdej fazie rozwoju projektu: „kontekst” jest tym małym słowem, które skrywa w sobie wszystkie przeróżne elementy bombardujące projekt od samego początku - mody rozpowszechniane przez krytyków w czasopismach architektonicznych, kalki utrwalone w umysłach niektórych klientów, zwyczaje zakorzenione w planach zagospodarowania przestrzennego, normy wpajane przez profesorów na uczelniach artystycznych i projektowych, przyzwyczajenia wizualne sprawiające, że mieszkańcy buntują się przeciwko nowopowstającym wzorom itp. Oczywiście, każdy nowy projekt modyfikuje wszystkie elementy, które próbują nadać mu kontekst, wywołując kontekstualne mutacje, tak jak maszyna Takamatsu (Guattari, 1994, s. 127-141). W takim znaczeniu projekt budynku zdecydowanie bardziej przypomina złożony ekosystem, niż statyczny obiekt w przestrzeni euklidesowej. Jak to już wykazało wielu architektów i teoretyków architektury, biologia oferuje doskonałe metafory do opisu budynków (Picon, Ponte, 2003).

Dopóki nie znajdziemy sposobu na odwrócenie tego, czego dokonał Marey, ukazując lot ptaków i chód koni, teoria architektury pozostanie przedsięwzięciem pasożytniczym, dodając po prostu historyczne, filozoficzne, stylistyczne i semiotyczne ,wymiary” do koncepcji budynków, które nie drgnęły nawet o cal (King, 1980; Leach, 1997; Borden, Rendell, 2000). Oznacza to, że zamiast analizować wpływ surrealizmu na myślenie i filozofię projektowania Rema Koolhaasa, powinniśmy raczej spróbować uchwycić kapryśne zachowanie pianki, z której budowano modele w jego pracowni. Zamiast odwoływać się do symbolizmu budynku naukowego, wyrażonego w architekturze Richards Medical Research Laboratories w Pensylwanii, powinniśmy raczej prześledzić, z jakim zapałem jego użytkownicy przeciwstawili się wizji architekta Louisa Kahna, wchodząc z budynkiem $\mathrm{w}$ trudne negocjacje, w których uczestniczyły również szyby i światło słoneczne. Zamiast wyjaśniać kształt siedziby Zgromadzenia w Czandigarh ograniczeniami finansowymi czy skromnym repertuarem konceptualnym modernizmu Le Corbusiera i jego unikalnym, nieeuropejskim stylem planowania całościowego, powinniśmy raczej zwrócić uwagę na różnorakie przejawy oporu stawianego przez ten budynek wiatrowi, słońcu, mikroklimatowi Himalajów itp. Teoria architektury stanie się ważną dziedziną dla architektów, użytkowników, inwestorów i budowniczych jedynie wówczas, gdy zacznie tworzyć takie ujęcia budynków i procesów projektowania, które będą stapały twardo po ziemi. Zamiast odnosić się do abstrakcyjnych ram teoretycznych spoza architektury, teoria ta powinna podążać za mnogością konkretnych bytów, współistniejących w określonej przestrzeni i czasie. Przed teorią architektury zostaje zatem postawione nowe zadanie: znaleźć odpowiednik

poświęcony „,mapowaniu” kontrowersji naukowych i technicznych. Celem projektu było promowanie partycypacji obywatelskiej i dostarczenie narzędzi teoretycznych, niezbędnych dla osób angażujących się w kwestie polityczne dotyczące rozwoju nauki oraz technologii. Zob. www.mappingcontroversies.net, http://www.medialab.sciences-po.fr/projets/macospol/, dostęp 14.11.2017 [przyp. thum.]. 
fotorewolweru Marey’a i podjąć niewątpliwie trudne wyzwanie wynalezienia słownika wizualnego, który ostatecznie odda sprawiedliwość „,rzeczowej” naturze budynków, nie sprowadzając ich do wyeksploatowanej, starej „obiektywności”.

Publikacja za zgodą właścicieli praw do tekstu.

\section{Bibliografia}

Bonta, J. (1979). Architecture and it's interpretation: A Study of Expressive Systems in Architecture. New York, NY: Rizzoli.

Borden, I., Rendell, J. (2000). Inter Sections: Architectural Histories and Critical Theories. London, UK: Routlege.

Bredekamp, H. (2004). Frank Gehry and the Art of Drawing. W: M. Rappold, R. Violette (red.), Gehry draws (s. 11-29). Cambridge, MA: MIT Press.

Busch, A. (1991). The Art of the Architectural Model. New York, NY: Design Press.

Guattari, F. (1994). Les Machines Architecturales de Shin Takamatsu. Chimères, 21(zima), 127-141.

Holl, S., Pallasmaa, J., Pérez-Gómez, A. (2006). Questions of Perception: Phenomenology of Architecture. San Francisco, CA: William Stout Architectural Books.

Houdart, S. (2006). Des multiples manières d'être réel. Les représentations en perspective dans le projet d'architecture. Terrain, 46, 107-122.

James J. Gibson, J.J. (1979). The Ecological Approach to Visual Perception. Boston, MA: Houghton Mifflin.

Jencks, Ch., Baird, G. (red.). (1969). Meaning in Architecture. London, UK: Barrie \& Rockliff, The Cresset Press.

King, A. D. (1980). Buildings and Society: Essays on the Social Development of the Built Environment. London, UK: Routledge \& Kegan Paul.

Latour, B. (2008). The Space of Controversies: An interview with Bruno Latour. New Geographies \#0: Design, Agency, Territory, 122-136.

Latour, B. (2014). Dajcie mi laboratorium, a poruszę świat. (K. Abriszewski, Ł. Afeltowicz, thum.). W: E. Bińczyk, A. Derra (red.), Studia nad nauka oraz technologia. Wybór tekstów (s. 139-178). Torun, Polska: Wydawnictwo Naukowe UMK.

Leach, N. (red.). (1997). Rethinking Architecture. Londyn, UK: Routlege.

Picon, A., Ponte, A. (2003). Architecture and the Sciences: Exchanging Metaphors. New York, NY: Princeton Architectural Press.

Porter, T. (1979). How Architects Visualize. New York, NY: Van Nostrand Reinhold. 
Venturi, R., Brown, D. S. (2004). Architecture as Signs and Systems. Cambridge, MA: Belknap Press of Harvard University Press.

Vesely, D. (2004). Architecture in the Age of Divided Representation: The Question of Creavity in the Shadow of Production. Cambridge, MA: MIT Press.

Yaneva, A. (2005). Scaling Up and Down: Extraction Trials in Architectural Design. Social Studies of Science, 35, 867-894.

\title{
Źródła internetowe
}

MACOSPOL (Mapping Controversies on Science for Politics), www.mappingcontroversies.net, http://www.medialab.sciences-po.fr/projets/macospol/, dostęp 14.11.2017.

\section{"Give Me a Gun and I Will Make All Buildings Move": An ANT's View of Architecture}

\begin{abstract}
Our building problem is just the opposite of Etienne Jules Marey's famous inquiry into the physiology of movement. Through the invention of his "photographic gun," he wanted to arrest the flight of a gull so as to be able to see in a fixed format every single successive freeze-frame of a continuous flow of flight, the mechanism of which had eluded all observers until his invention. What we need is the reverse: the problem with buildings is that they look desperately static. It seems almost impossible to grasp them as movement, as flight, as a series of transformations. Everybody knows - and especially architects, of course - that a building is not a static object but a moving project, and that even once it is has been built, it ages, it is transformed by its users, modified by all of what happens inside and outside, and that it will pass or be renovated, adulterated and transformed beyond recognition. We know this, but the problem is that we have no equivalent of Marey's photographic gun: when we picture a building, it is always as a fixed, stolid structure that is there in four colors in the glossy magazines that customers flip through in architects' waiting rooms. If Marey was so frustrated not to be able to picture in a successive series of freeze-frames the flight of a gull, how irritating it is for us not to be able to picture, as one continuous movement, the project flow that makes up a building. Marey had the visual input of his eyes and was able to establish the physiology of flight only after he invented an artificial device (the photographic gun); we too need an artificial device (a theory in this case) in order to be able to transform the static view of a building into one among many successive freeze-frames that could at last document the continuous flow that a building always is.
\end{abstract}

Keywords: ANT; architecture; building; movement; project. 